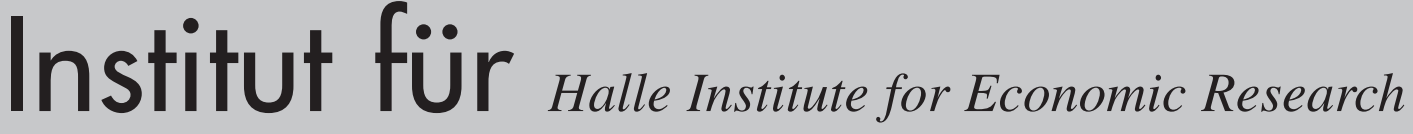 Wirtschaffsforschung Halle
}

\section{The unemployment-growth relationship} in transition countries

\author{
Hubert Gabrisch \\ Herbert Buscher
}

November 2005

No. 5

\section{IWH-Diskussionspapiere IWH-Discussion Papers}


Autoren: Dr. Hubert Gabrisch, Forschungsdirektor

Hubert.Gabrisch@iwh-halle.de

Tel.: 0345 7753-830

Dr. Herbert Buscher, Leiter der Abteilung Arbeitsmarkt- und Einkommensökonomik Herbert.Buscher@iwh-halle.de

Tel.: 0345 7753-770

The responsibility for discussion papers lies solely with the individual authors. The views expressed herein do not necessarily represent those of the IWH. The papers represent preliminary work and are circulated to encourage discussion with the author. Citation of the discussion papers should account for their provisional character; a revised version may be available directly from the author.

Comments and suggestions on the methods and results presented are wellcome.

Herausgeber:

INSTITUT FÜR WIRTSCHAFTSFORSCHUNG HALLE - IWH

Prof. Dr. Ulrich Blum (Präsident), Dr. Hubert Gabrisch (Forschungsdirektor)

Das IWH ist Mitglied der Leibniz-Gemeinschaft

Hausanschrift:Kleine Märkerstraße 8, 06108 Halle (Saale)

Postanschrift: Postfach 1103 61, 06017 Halle (Saale)

Telefon:

(0345) 77 53-60

Telefax:

(0345) 77 53-8 20

Internetadresse: http://www.iwh-halle.de 


\title{
The unemployment-growth relationship in transition countries
}

\begin{abstract}
Does the disappointingly high unemployment in Central and East European countries reflect non-completed adjustment to institutional shocks from transition to a market economy, or is it the result of high labour market rigidities, or rather a syndrome of too weak aggregate demand and output? In the case of transitional causes, unemployment is expected to decline over time. Otherwise, it would pose a challenge to the European Union, particular in case of accession countries, for it jeopardizes the ambitious integration plans of, and may trigger excessive migration to the Union. In order to find out which hypothesis holds 15 years after transition has started, we analyze the unemploymentgrowth dynamics in the eight new member countries from Central-Eastern Europe. The study is based on country and panel regressions with instrument variables (TSLS). The results suggest to declare the transition of labour markets as completed; unemployment responds to output and not to a changing institutional environment for job creation. The regression coefficients report a high trend rate of productivity and a high unemployment intensity of output growth since 1998. The conclusion is that labour market rigidities do not to play an important role in explaining high unemployment rates. Rather, GDP growth is dominated by productivity progress, while the employment relevant component of aggregate demand is too low to reduce substantially the high level of unemployment.
\end{abstract}

JEL classifications: E24, J23, P23

Keywords: Unemployment, Okun's law, Transition 


\section{Introduction}

Participation and employment rates are lower in most European transition countries than in the old EU-15 countries, but their unemployment rates and GDP growth rates are mostly higher (EU Commission 2004). The disappointing labour market performance may cause excessive emigration and jeopardize political integration of the EU. The literature in research concentrates on three hypothesis: high unemployment is either still a response to ongoing adjustment processes stemming from incomplete transition, or reflects labour market rigidities, or roots in too weak economic growth. The objective of this paper is to present a comprehensive perspective on unemployment dynamics in transition countries in order to (a) measure the responsiveness of labour markets to economic growth, (b) apply a macroeconomic measure for advances in transition to a market economy, and (c) assess unemployment thresholds of growth. We try to find out whether there is a robust relationship between unemployment and output changes, an approach related to Okun's law. First, this law applies to a fully-fledged market economy. If confirmed, persistent unemployment cannot be explained by incomplete transition. Second, the coefficients of the tested relationship reflect the role labour market rigidities play in transforming output growth into less unemployment. Third, with given rigidities, unemployment is a matter of output growth, ruled by trend productivity and aggregate demand.

The rest of the paper is organized as follows: Section 2 illustrates the stylized facts of labour market dynamics in transition countries with a focus on the 8 new EU members, and provides a literature survey. Section 3 presents the empirical strategy of the study. We test an empirical version of Okun's law, and apply formal tests to the data and the regression results. Furthermore, we use single equation as well as panel regression techniques in order to find evidence for transition impacts. Section 4 reports the test results. It seems that in most countries the unemployment rate is not overwhelmingly affected by transition, but rather by weak GDP growth. Unemployment thresholds of growth are rather high due to fast progress in total factor productivity. Finally, section 5 concludes, relating the empirical results to the politically relevant issue of unemployment dynamics in the enlarged Union. 


\section{Stylized facts and state of research}

Output development, measured as GDP growth rates, took the form of a J-curve in most transition countries (see Figure 1). The course unemployment took was visibly different. The first stage - between about 1990 and 1993/94 - knows a remarkable decline of GDP, mainly due to various shocks on domestic aggregate demand and supply, among them shocks on trade among the countries. The second stage shows a remarkable recovery, which lasted until about 1997 . This period is the so-called J-curve in output. It was followed by slow down of growth rates until 2002-03, after a new wave of external shocks (financial crises) hit some countries and forced others to consolidate their fiscal balances and increase interest rates. At first glance, unemployment seems to have followed with some delay. In the first stage with massive output declines in 1990-1992, unemployment rates did not increase with the same force, although unemployment in the later accession countries reached a first peak with more than $4 \mathrm{mn}$ persons in 1994, of which in Poland alone $2.4 \mathrm{mn}$ persons. The aggregate unemployment rate of this region of eight countries was at about 12 per cent. But with accelerating recovery in output between 1994 and 1997, the unemployment rate of the 8-country region fell slightly to some 10 per cent in 1997. But then, it increased again, reaching a new peak in 20022003 with low but yet positive growth rates of output.

With recessive trends and deteriorating financing output started to stagnate; even the private sector was not able to absorb dismissed workers, and employment in private in

Figure 1:

The stylized course of output and unemployment during transition

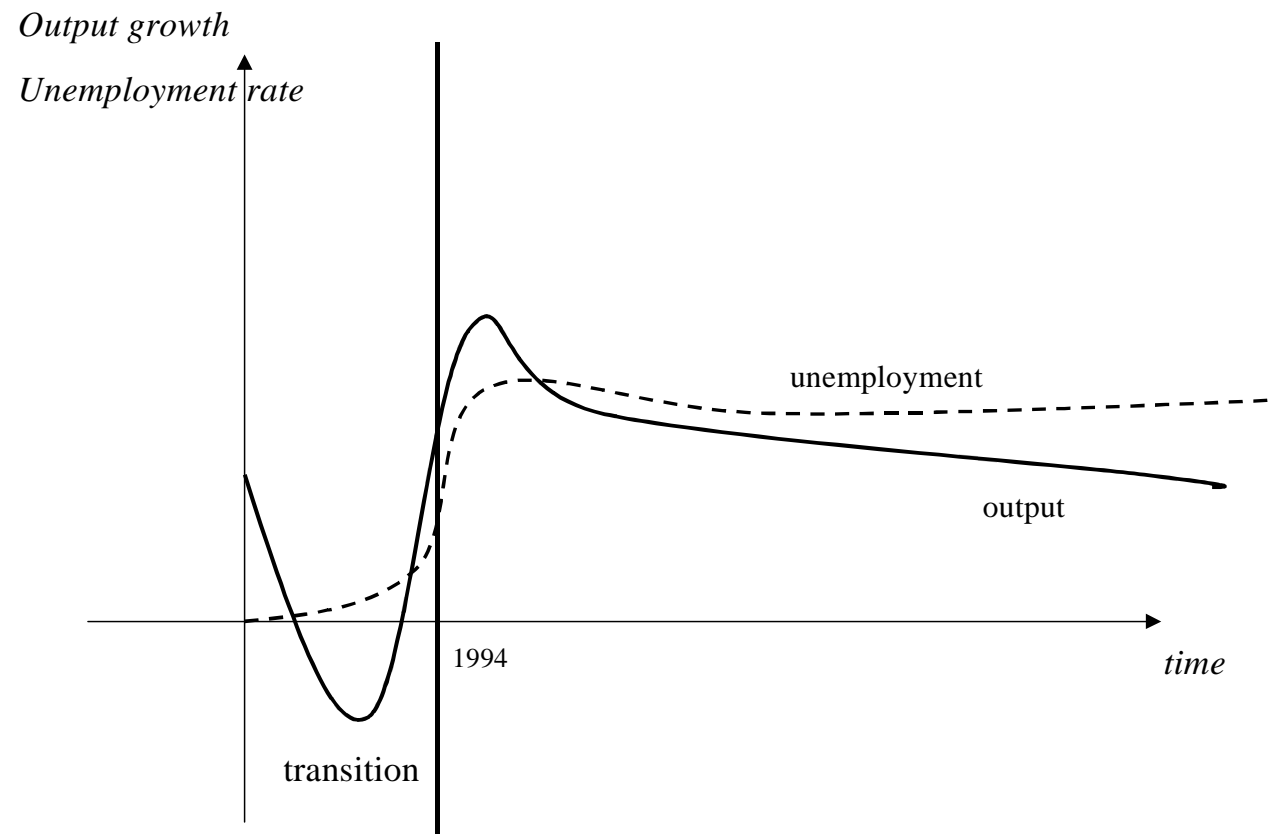


dustry even started to fall. However, the stylized facts seem not to link strictly output and unemployment, at least not in the first stage of transition.

The different course of unemployment compared to output seems indeed in line with privatization and related institutions: 'Spontaneous' (unregulated) privatization and first restructuring attempts in state-owned enterprises reduced employment in the state industry, and with already liberalized labour markets, the de novo private sector absorbed a part of the work force redundant in the socialist sector. In addition, the inherited institutional conditions of the centrally planned economy were still at work; state-owned enterprises did not yet respond to demand shocks and relative price changes. With beginning legal privatization - far going mass privatization in the Czech and Slovak Republics in 1993 -, unemployment rose quickly, although output decline phased out. Spreading restructuring measures in privatized firms led to large dismissals in the period that followed, whereby the extent of employment restructuring depended on the method of privatization. For example, mass privatization and management-employees-buy-outs entailed initially less dismissals, compared with direct sales to foreigners. In addition, the bankruptcy regulation had an effect on employment. But with accelerating recovery in output between 1994 and 1997, the emerging private sector was still able to absorb a large portion of the workers dismissed in state industry. More effective corporate governance and foreign investors supported the ongoing restructuring in the almost completely privatized sector.

There are partly severe country and regional differences behind the general picture, reflected in different unemployment rates in 2003 (Table 1). Most EU candidate countries are small economies, exerted to supply and price shocks in the World economy. The large size of Russia and its richness in energy made many politicians to believe that the necessary adjustment in institutions and on the labour market can be delayed. However, the transition crisis after the Gajdar reforms of 1992 lasted longer (until 1998) than in other transition countries. Also, unemployment rates remained below, for maintaining old structures and institutions preserved excessive labour in state-owned and privatized enterprises. The recent increase in world market oil prices and the devaluation of the rouble during the financial crisis in August 1998 helped the Russian economy to overcome the long-lasting stagnation and decline and contributed to a fall in the unemployment rate.

The Baltic States are not only the smallest transition countries. Being a part of the Soviet Union, they were more dependent on the disintegration of the Union and on each other, which contributed to strong external shocks during the first stage of independency. Most countries suffered a loss in population, most severely in the Baltic States. Estonia lost 14\% of its population between 1990 and 2004. More than half of this loss attributed to emigration (Latvia: 24\%, Lithuania: 13\%). In these countries, the Russian speaking population tended to emigration after the withdrawal of the Russian military, and after the introduction of many laws and regulations discriminating the Russian minority (Hazans, 2004). With unchanged participation rates, unemployment rates would have 
Table 1:

Unemployment and participation rates in transition countries, in per cent, 2003

\begin{tabular}{|c|c|c|c|c|}
\hline \multirow[t]{2}{*}{ Country } & \multirow{2}{*}{$\begin{array}{l}\text { Unemployment rate } \\
2003\end{array}$} & \multicolumn{2}{|c|}{ Participation rate } & \multirow{2}{*}{$\begin{array}{c}\text { Calculated unemployment rate } \\
2003\end{array}$} \\
\hline & & 1990 & 2003 & \\
\hline \multicolumn{5}{|l|}{ EU member countries ${ }^{a}$} \\
\hline Czech Republic & 7.8 & 78.4 & 70.2 & 17.5 \\
\hline Estonia & 10.2 & 80.9 & 70.0 & 22.2 \\
\hline Hungary & 5.8 & 62.0 & 60.5 & 8.1 \\
\hline Latria & 10.4 & 79.4 & 69.1 & 22.2 \\
\hline Lithuania & 12.7 & 73.6 & 70.0 & 14.9 \\
\hline Poland & 19.2 & 68.4 & 63.4 & 25.2 \\
\hline Slovak Republic & 17.5 & 72.2 & 69.6 & 21.4 \\
\hline Slovenia & 6.5 & 71.5 & 67.0 & 12.4 \\
\hline \multicolumn{5}{|l|}{ Candidate countries $^{b}$} \\
\hline Bulgaria & 13.5 & Not available & 61.0 & - \\
\hline Romania & 7.2 & Not available & 62.0 & - \\
\hline \multicolumn{5}{|l|}{$\mathbf{C I S}^{\mathbf{b}}$} \\
\hline Russian Federation & 2.3 & Not availa & & - \\
\hline Ukraine & 3.6 & Not availa & & - \\
\hline
\end{tabular}

${ }^{\mathrm{a}}$ EU-OECD standardized unemployment rate: in per cent of the civilian labour force. $-{ }^{\mathrm{b}}$ Registered unemployment rate in per cent of the labour force.- ${ }^{c}$ Total employment plus unemployment $(15+)$ in per cent of the population (1564). $-{ }^{d}$ At 1990 participation rates.

Source: UN-Economic Commission for Europe, 2005; EU-Commission, 2004; authors' calculations.

been higher. The Baltic States liberalized their external trade with more extent (Baltic Free Trade Agreement) than the other transition countries, so that their labour markets should be more integrated than between the members of the Central European Free Trade Association (CEFTA). Slovenia's relatively low unemployment rate might be a possible outcome of a more restrictive employment protection law than in other countries (Cazes, 2003). Poland and the Slovak Republic report extremely high unemployment rates. Low unemployment rates are partly to explain by early retirement schemes and emigration. The Polish government sent almost $1 \mathrm{mn}$ people into early retirement. The Hungarian government sent many employed pensioners into inactivity 1 that had contributed to the almost full employment state. In some countries, cuts of unemployment benefits reduced incentives for unemployed to register. Unemployed joined the hidden reserve or took a job in the shadow economy. The Czech government softened the budget constraints of state-owned enterprises and slowed reforms in the public sector (administration, education etc.) after the first transition shocks hit the labour market unexpectedly strongly. After the financial crisis of 1997, new governments tried to re-

1 Contrary to other countries, the retiring age was very low in Hungary (55 for women and 60 for men). 
vive the recessive trends in the economy by lifting fiscal restrictions and a more expansive monetary policy.

The literature offers three perspectives on the link between unemployment and transition. The macroeconomic perspective explains unemployment with transitional aggregate demand and supply shocks. The output decline in the early stage of transformation is explained either by a demand shock due to excessive stabilization policy (see for many others: Bhaduri and Laski 1997, and Kornai, 1993, partly for Hungary), or by supply side factors like the depreciation of the inherited capital stock ('useless stocks', see among others Borensztein and Montiel 1991). After 1997, the financial crises in South-East Asia threatened to spread over all emerging market economies, and let to a general decline of world economic activities. Governments of transition countries reacted by more efforts in consolidating the fiscal balance and by monetary restriction to suppress domestic demand and to improve the external position. The unanswered question is why unemployment is still at a high level, when the level of output in 2003 has exceeded the pre-transition level in most countries?

The institutional perspective seems to explain this phenomenon in essence. While it disregards aggregate demand and supply shocks, unemployment is explained with the conflicts between inherited and new institutions. The most influential theory is the Optimal Speed of Transition (OST) theory (Aghion and Blanchard 1994, Garibaldi and Brixiova 1997, Castanheira and Roland 2000). The basic idea is to relate the rise of the private sector to its profitability, which depends on the speed of restructuring the state sector, whereby this speed depends on government action, the privatization process and the behaviour of the workers in state-owned enterprises. However, empirical research on the OST theory suffers from weak data availability and often remained primarily a theoretical exercise (Haltiwanger, Lehmann, and Terell 2003). Although some authors try to rely on empirical evidence (for example, Boeri and Terell, 2002), their work remains far from the application of the usual formal tests. A basic problem here is the singularity of transition, which restricts the number of observations.

A recent strand of the institutional approach is to assume transition as completed and to investigate on the possible relation between unemployment and labour market rigidities in market economies (EBRD 2000, Nesperova 2002). The suspicion is that the new market economies suffer from the same 'Eurosclerosis' like the old EU members. The idea is to find out whether the differences in unemployment rates of OECD countries are related to different levels of labour market rigidity ((Nickell 1997, Layard and Nickell 1999, OCED 1999). The empirical picture remains ambiguous. The $O E C D$ employment outlook for 2003 finds that Beveridge curves do not stand for more rigidity in the Czech Republic, Hungary, and Poland. Also, Cazes (2002) finds that the various indicators describing the rigidities on the labour market are at a lower level than in OECD countries. There remains the question what is responsible for weak labour market performance in transition countries? Can we find an approach, which links all three hypotheses in one framework? 


\section{Empirical strategy}

\section{The model}

We estimate country and panel data equations according to the model

(1) $\Delta U_{t}=\alpha_{0}+\alpha_{1} y_{t}+\alpha_{2} \Delta U_{t-1}+\alpha_{3} D+\varepsilon_{t}$

where $\alpha_{0}$ is trend rate of GDP stemming from progress in total factor productivity or technology, $\alpha_{1}$ is the coefficient to the growth rate of actual output or aggregate demand. It reflects the ability of the labour market to transform growth into less unemployment. The higher the coefficient, the lower is the market rigidity. $\Delta U_{t-1}$ is the lagged dependent variable, which captures dynamic adjustment, and $\varepsilon_{t}$ is the disturbance term. D is a $(0,1)$ dummy, which is inserted into the equation in order to capture structural breaks, if necessary. Equation (1) is the empirical version of Okun's first difference models (1962 and 1983). 'Okun's law' has been successfully tested in many early and recent studies on OECD countries (for example, Prachowny 1993, Döpke 2001, Sögner and Stiassny 2002). A recent study by Izyumov and Vahaly (2002) confirmed it also for transition countries; however, their approach needs more formal testing. Although the law is sometimes described as 'a-theoretical', it can be derived from a short-term production function (see Sögner and Stiassny 2002), where output is driven by aggregate demand. The demand for and supply of labour depends on the nominal wage rate and aggregate demand - the standard model of the labour market. We neglect further objections to this choice of the theoretical model ${ }^{3}$, and focus our discussion to the two basic approaches of the law. The first approach (the 'gap' model) relates deviations of the actual unemployment rate and actual GDP from equilibrium values. In empirical research on OECD countries, deviations of the unemployment rate from NAIRU are regressed on the gap between actual and potential GDP. The estimation of potential output and NAIRU is a well-known problem in the analysis of market economies, and it is a probably more tricky task in the case of transition economies with their possible structural breaks 4 We do not follow the attempt of Cazes (2002) to calculate trend data as a proxy for potential output growth in transition countries. The trend deviation concept is somewhat obscure, for it reduces the connotation of the output gap to exclusively cyclical movements of actual output, neglecting possible long-term weaknesses in aggregate

2 In Okun's work, the unemployment rate was the explanatory variable, and output the variable to explain. In most empirical research that followed, the relation has been tested the other way round.

3 We neglect the critical literature on Okun's law, stating that it does not consider the impact of relative factor prices (Prachowny 1993), in particular real wages (Flaig and Rottmann 2000). This model is derived from micro economic cost optimization (via 'Shephard's lemma'), and demand for and supply of labour depends on the relative real wage.

4 For a recent attempt to estimate NAIRU figures for transition countries, see Camarero et al. (2005). 
demand (see Solow's critique, 2000, p. 9) or changes in the capital-labour ratio (Prachowny 1993). Applying NAIRU data would also narrow the approach to cyclical variations of aggregates. The second approach is to regress changes in the actual unemployment rate on first differences of the log of actual output (= growth rate). Okun itself recommended this approach in case when potential output cannot be reasonably estimated, as one can assume for transition economies. In this approach, the cyclical connotation does not play any role. This version of Okun's law allows to test simply for a response of the unemployment rate to output variations, and the coefficients give an idea how high the growth rates of aggregate demand or actual output need to be in order to reduce unemployment.

If the law applied, the constant and the lagged variable should obtain a positive sign, and the coefficient to output a negative sign. The long-run unemployment intensity of growth is obtained by deleting the time subscript and to solve for $y$ : Then a fall in the unemployment rate by 1 percentage point requires an output growth rate of $\left(1 / \alpha_{1}\right)\left(1-\alpha_{2}\right)$.

\section{Data and pre-test}

We use annualized data of quarterly first differences in unemployment rates, and real GDP growth rates in eight accession countries from Central-East Europe from the first quarter 1994 until the fourth quarter 2004 (see Appendix for data tables A, B, C, and D). We consider registered unemployment as well as Labour Force Survey (LFS) unemployment rates, so far available (for detailed information, see Appendix). We test for unit roots and the quality of regression results. Equation (1) is a linear-function type, assuming stationarity that means, there should not be a unit root in the data. For most industrialized Western countries one can expect GDP and unemployment data to be stationary. For countries in transition, the descriptive statistics have shown that things might be different. A typical feature of non-stationarity is, for example, the J-curve region leftward of the diving 1994 line in Figure 1. The J-curve suggests the exclusion of any linear relationship between the unemployment rate and output variations, even if the regression would produce the expected outcome in sign and significance. One may risk saying that until 1994, most time series were not stationary due to the early transition shocks, while in the later period (for which more data is available), the picture is more uncertain.

\section{Regressions}

The study starts with single country regressions. Among the available battery of tests for appropriateness of the model specification, we control for stability (CUSUM and CUSUM squared statistics), autocorrelation (Q statistics) and normality in distribution (JB). We compare results of two periods: the first period consists of the entire time span (1994:1 throughout 2004:4), the second one narrows to the later transition period (1998:1 until 2004:4). We complete with panel regressions technique, for one cannot as- 
sume that the countries under investigation are independent from each other. Instead it seems more plausible to assume that neighbouring countries such as the Baltic States develop in a similar fashion and that many characteristics of the countries are the same, which might imply that their economic performances are highly correlated. The panel approach assumes the same slope ('Okun') coefficient for all countries. A fixed effects estimator captures time-invariant differences between countries, for example language, size, and location. The use of fixed effects estimators is meaningful for fully-fledged market economies, but not a priori for countries on their way to a market economy, where cultural and other time-invariant specifics might be overlaid by transition specifics. In this case, the more restrictive pooled regression approach (like applied by Izyumov and Vahaly, 2002)) is more appropriate, assuming that even the constant term is equal across countries. In all cases we used the White robust estimator to account for possible heteroskedasticity as well as serial correlation of unknown form. This yields consistent standard errors of the coefficient estimates.

Standard OLS regressions with a dynamic variable (here: $\Delta U_{t-1}$ ) are characterized by the well-known econometric problem of endogeneity of one of the explanatory variable that is, this variable is correlated with the error term. In order to minimize the risk of distortions TSLS regressions with instrumental variables are used in single equations as well as panel equations. Natural instruments are sufficiently lagged variables of the endogenous and exogenous variables; here one can assume that they are not correlated with the error term, but still correlated with the variables to be instrumented. In addition, we apply some other instruments like the US registered unemployment rate and the treasury bills rate, and total exports of the accession country considered. 


\section{Test results}

\section{Unit roots}

The ADF-test is probably the most applied test in the unit root framework. At it is well known, this test suffers from serious size distortions (short time series) and a low power, and should therefore be interpreted with caution (Maddala and Kim 1998). In addition to the ADF-test we also apply the KPSS test. Looking at both to perform a test of stationarity against non-stationarity we expect to gain more insights into the true but unknown data generating process.

Table 2:

Results of Unit Root Tests

\begin{tabular}{|c|c|c|c|c|}
\hline Country & Variables & Time period & $\begin{array}{c}\text { ADF-Test } \\
2 \text { lags } \\
\end{array}$ & KPSS-Test \\
\hline \multirow{4}{*}{$\begin{array}{l}\text { Czech } \\
\text { Republic }\end{array}$} & Real GDP & $94: 3-04: 4$ & -2.253 & 0.181 \\
\hline & Reg. unemployment rate & $94: 3-04: 4$ & -2.503 & 0.123 \\
\hline & LFS unemployment rate & $94: 4-04: 4$ & -2.583 & 0.121 \\
\hline & Real GDP & $94: 4-04: 4$ & $-5.135 * * *$ & 0.213 \\
\hline \multirow[t]{3}{*}{ Estonia } & Reg. unemployment rate & $94: 3-04: 4$ & -2.538 & 0.313 \\
\hline & LFS unemployment rate & $94: 2-04: 4$ & -2.339 & 0.326 \\
\hline & Real GDP & $94: 2-04: 4$ & -1.741 & 0.300 \\
\hline \multirow[t]{3}{*}{ Hungary } & Reg. unemployment rate & $94: 2-04: 4$ & -1.486 & $0.464 * *$ \\
\hline & LFS unemployment rate & $94: 2-04: 4$ & -1.477 & $0.536 * *$ \\
\hline & Real GDP & $94: 4-04: 4$ & 2.402 & $0.476 * *$ \\
\hline \multirow[t]{3}{*}{ Latvia } & Reg. unemployment rate & $94: 2-04: 4$ & $-4.505 * * *$ & 0.189 \\
\hline & LFS unemployment rate & n. a. & n. a. & n. a. \\
\hline & Real GDP & $94: 1-04: 4$ & $-3.713 * * *$ & 0.143 \\
\hline \multirow[t]{3}{*}{ Lithuania } & Reg. unemployment rate & $95: 3-04: 4$ & -1.331 & $0.433 * *$ \\
\hline & LFS unemployment rate & n. a. & n. a. & n. a. \\
\hline & Real GDP & $94: 3-04: 4$ & -2.036 & 0.213 \\
\hline \multirow[t]{3}{*}{ Poland } & Reg. unemployment rate & $94: 3-04: 4$ & -1.780 & 0.251 \\
\hline & LFS unemployment rate & $94: 2-04: 4$ & $-3.492 * *$ & 0.164 \\
\hline & Real GDP & $95: 1-04: 4$ & $3.610 * * *$ & 0.298 \\
\hline \multirow[t]{3}{*}{ Slovakia } & Reg. unemployment rate & $94: 3-04: 4$ & -2.187 & 0.203 \\
\hline & LFS unemployment rate & $94: 3-04: 4$ & $-3.652 * * *$ & 0.284 \\
\hline & Real GDP & $95: 1-04: 4$ & $-3.610 * * *$ & 0.299 \\
\hline \multirow[t]{2}{*}{ Slovenia } & Reg. unemployment rate & $94: 3-04: 4$ & $-2.955 * *$ & 0.189 \\
\hline & LFS unemployment rate & $97: 3-04: 4$ & -2.574 & $0.373^{*}$ \\
\hline
\end{tabular}

$*, * *, * * *$ indicates significance at the 10,5 , and $1 \%$ level.

LFS: $\quad$ Labour Force Survey; n. a. : not available.

Out of the 22 single series tested for stationarity, the ADF tests reject stationarity in eight cases, whereas the KPSS tests do so in only six cases. Among these cases rejections appears four times for the first differences in the unemployment rate based on LFS data and only twice for registered unemployment. In the overwhelming cases of GDP and registered unemployment data the KPSS tests indicate stationarity of the data series. 
The cases where the ADF test rejects stationarity do not overlap with the cases where the KPSS tests reject it. But given the short time series at hand we think that the results of the KPSS tests are slightly more reliable than those of the ADF tests. Following the results of the KPSS tests, stationarity of GDP growth is only rejected for Latvia; the remaining cases relate to the registered unemployment rates of Hungary and Lithuania. By and large and based on these test results, estimation of the Okun relationship should be allowed. The slightly weaker results of KPSS tests for LFS data support our doubts with respect to the LFS approach in transition countrie. This instability in the divergence of the two unemployment rates and their first differences could stem from weak survey pre-conditions. Labour force surveys require particular trust into the interviewers' engagement and into the answers of interviewees, to ensure a realistic picture. We do not expect this quality for transition countries at a level like in OECD countries. 5 Therefore, we drop regressions with LFS data and use registered unemployment only.

\section{Country regressions}

In OLS regressions the applied test battery detected some structural breaks for the Czech Republic and Lithuania, all located in the year of EU accession (see Appendix Table D). In TSLS estimations with instruments and time dummies capturing these breaks, coefficients have the expected signs, but are not significant in most cases (Table 3). Qstatistics report a high autocorrelation five countries, with respect to the entire period. The results suggest accepting aggregate demand changes being responsible for unemployment in the Czech Republic only. Unemployment seems to be affected by transition-specific determinants, so far a period is included, which is still very close to the first transition stage until 1994.

Estimates of the later period 1998:1 - 2004: 4, yield a remarkable improvement in significance and sensitiveness of results (Table 4). Okun's law seems to be confirmed with appropriate distance to the beginning of transition, while until 1998 the strong increase of unemployment seems to be caused by still institutional and macroeconomic shocks. Okun coefficients are between 0.85 (Hungary) and 2.3 (Latvia), which seems to report a rather high responsiveness of the unemployment rate to changes in actual GDP growth rates. 6 Poland and Slovakia are the two exceptions, where an unemployment-output relationship could not be detected even in this later period, although various transition indictors suggest no larger delay compared with the other countries (EBRD 2004). Both countries report the highest unemployment rates among the accession countries. We ex-

5 The World Value Studies and European Value Studies (Halman 2001) revealed a comparatively low level of interpersonal trust in all former socialist countries compared with the well-established democracies of most OECD countries.

6 Okun obtained a coefficient of 3 for the US economy, which serves as benchmark for many other empirical studies. 
Table 3:

Registered unemployment rate (first differences); TSLS regressions: Period: 94:2 - 04:4; observations: 43

\begin{tabular}{|c|c|c|c|c|c|c|c|c|c|}
\hline \multirow[b]{2}{*}{ Country } & \multicolumn{4}{|c|}{ Coefficients } & \multirow{2}{*}{$\underset{\mathrm{R}^{2}}{\text { Adj. }}$} & \multirow{2}{*}{$\begin{array}{c}\text { Q- } \\
\text { stat(10) }\end{array}$} & \multirow[b]{2}{*}{ JB } & \multirow[b]{2}{*}{ Instruments } & \multirow{2}{*}{$\begin{array}{c}\text { MA(1) } \\
\text { compared } \\
\text { to OLS }\end{array}$} \\
\hline & Constant & $y_{t}$ & $\Delta U_{t-1}$ & Dummy & & & & & \\
\hline $\begin{array}{l}\text { Czech } \\
\text { Republic }\end{array}$ & $0.003 * *$ & $-0.098 * *$ & $0.770 * * *$ & $\begin{array}{l}-0.002 \\
(04: 3)\end{array}$ & 0.873 & 9.05 & 1.04 & $\begin{array}{l}5,6,3, \\
2(-2) ; 1(-2)\end{array}$ & $\begin{array}{l}\text { Improve- } \\
\text { ment in Q }\end{array}$ \\
\hline Estonia & 0.006 & -0.127 & 0.275 & - & 0.530 & $36.82 * * *$ & 0.237 & $\begin{array}{l}5,6,3, \\
2(-2) ; 1(-2)\end{array}$ & - \\
\hline Hungary & 0.002 & -0.054 & $0.928 * * *$ & - & 0.584 & $18.69 * *$ & 1.08 & $\begin{array}{l}6,1(-3), \\
2(-3), 7,4 \\
\end{array}$ & \multirow{4}{*}{$\begin{array}{l}\text { no } \\
\text { improve- } \\
\text { ment }\end{array}$} \\
\hline Latvia & 0.007 & -0.1010 & $0.470 * * *$ & - & 0.477 & $23.01 * * *$ & 0.22 & $\begin{array}{l}6,1(-2), \\
2(-2)\end{array}$ & \\
\hline Lithuania & 0.005 & $-0.103 *$ & $0.782 * * *$ & $\begin{array}{l}-0.029 * * * \\
(04: 1)\end{array}$ & 0.858 & $26.14 * * *$ & 0.457 & $\begin{array}{l}6,1(-2), \\
2(-2), 3,7,5\end{array}$ & \\
\hline Poland & 0.005 & -0.118 & 0.798 & - & 0.846 & $18.68 * *$ & 1.19 & $\begin{array}{l}6,1(-2), \\
2(-2), 3,7\end{array}$ & \\
\hline Slovakia & 0.007 & -0.178 & $0.693 * * *$ & - & 0.792 & 11.11 & 2.33 & $\begin{array}{l}6,1(-2) \\
2(-2), 7,7(-1)\end{array}$ & $\begin{array}{l}\text { Improve- } \\
\text { ment in Q }\end{array}$ \\
\hline Slovenia & 0.006 & $-0.203 *$ & $0.674 * * *$ & & 0.520 & $18.11 * *$ & 2.57 & $\begin{array}{l}6,1(-2), \\
2(-2)\end{array}$ & $\begin{array}{l}\text { No im- } \\
\text { prove- } \\
\text { ment in Q }\end{array}$ \\
\hline
\end{tabular}

$* 10 \%, * * 5 \%, * * * 1 \%$

Instruments: (1) GDP growth rate; (2) registered unemployment rate (first difference); (3) US treasury bill; (4) US registered unemployment rate (first difference); (5) dummy; (6) constant; (7) growth rate of total exports.

Table 4:

Registered unemployment rate (first differences); TSLS results: Period: 98:1 - 04:4 N: 28

\begin{tabular}{|c|c|c|c|c|c|c|c|c|c|}
\hline \multirow{2}{*}{ Country } & \multicolumn{4}{|c|}{ Coefficients } & \multirow{2}{*}{$\underset{\mathrm{R}^{2}}{\text { Adj. }}$} & \multirow{2}{*}{$\begin{array}{c}\text { Q- } \\
\text { stat(10) }\end{array}$} & \multirow{2}{*}{ JB } & \multirow{2}{*}{$\begin{array}{l}\text { Instru- } \\
\text { ments }\end{array}$} & \multirow{2}{*}{ MA(1) } \\
\hline & Constant & $y_{t}$ & $\Delta U_{t-1}$ & Dummy $^{\mathrm{a}}$ & & & & & \\
\hline $\begin{array}{l}\text { Czech } \\
\text { Republic }\end{array}$ & $0.004 * *$ & $-0.163 * * *$ & $0.795^{* * *}$ & $\begin{array}{l}-0.002 \\
(04: 3)\end{array}$ & 0.895 & 15.51 & 0.89 & $\begin{array}{l}5,6,3 \\
2(-2) ; \\
1(-2)\end{array}$ & - \\
\hline Estonia & $0.007 * *$ & $-0.133 * * *$ & $0.741 * * *$ & - & 0.880 & 5.79 & $13.02 * * *$ & $\begin{array}{l}5,6,3 \\
2(-2) ; \\
1(-2)\end{array}$ & - \\
\hline Hungary & $0.006^{*}$ & $-0.142 *$ & $0.878 * * *$ & - & 0.647 & 6.64 & 1.53 & $\begin{array}{l}6,1(-2), \\
2(-2), 3\end{array}$ & - \\
\hline Latvia & $0.019 *$ & $-0.279^{*}$ & $0.357 * *$ & - & 0.829 & 8.67 & 0.79 & $\begin{array}{l}6,1(-2), \\
2(-2)\end{array}$ & $\begin{array}{l}\text { Improve- } \\
\text { ment in Q }\end{array}$ \\
\hline Lithuania & $0.004 *$ & $-0.080 * *$ & $0.885^{* * *}$ & $\begin{array}{l}-0.029 * * * \\
(04: 1)\end{array}$ & 0.923 & 15.1 & 3.06 & $\begin{array}{l}6,1(-2), \\
2(-2), 3, \\
7,5\end{array}$ & - \\
\hline Poland & 0.025 & -0.544 & 0.533 & - & 0.616 & 11.68 & 1.93 & $\begin{array}{l}6,1(-2), \\
2(-2)\end{array}$ & - \\
\hline Slovakia & 0.013 & -0.327 & 0.602 & - & 0.730 & 12.01 & 1.76 & $\begin{array}{l}6,1(-2), \\
2(-2)\end{array}$ & - \\
\hline Slovenia & 0.005 & $-0.160^{*}$ & $0.818 * * *$ & - & 0.632 & $24.66 * * *$ & 0.86 & $\begin{array}{l}6,1(-2), \\
2(-2), 7\end{array}$ & $\begin{array}{l}\text { No improve- } \\
\text { ment in Q }\end{array}$ \\
\hline
\end{tabular}

${ }^{a}$ in brackets: the runaway quarter. $-* 10 \%, * * 5 \%, * * * 1 \%$

Instruments: see Table 3. 
plain this results with sector- and industry-specific transition characteristics. In Poland, low-productive agriculture plays a dominant role for the economy's ability to absorb part of the labour force. However, strong productivity increases in this sector and in manufacturing might be the reason for the yet not existent linkage between GDP growth and unemployment. In Slovakia, this linkage seems to be distorted by the adjustments in the comparably large share of the armament industry, and by some delayed transition efforts after 1998. Okun coefficients are between 1.25 (Lithuania) and 7 (Hungary), and move in the range observed for OECD countries (Döpke 2001, Sögner and Stiassny 2002).

\section{Panel regressions}

The results of panel regression presented in Table 5 are highly significant with respect to the later period. This statement holds for the least squares as well as for the instrument estimates. F-values of instrument estimates show that the pooled regressions are rejected in favour of the fixed effects model in the later period. A relevant part of the unemployment rate seems to emerge from time-invariant country-specific determinants: fixed effects are more divergent among countries in the later than in the entire period. We understand this as a confirmation of that the time-variant transition impact on unemployment has phased out. The rejection of Okun's law for Poland and Slovakia in country equations has no impact on the panel regressions. We explain this by a minor relevance of transition specifics in both countries; furthermore, interdependencies between the countries might have distorted the single equations compared with the panel model. The constant increases in all regressions over time, reporting high productivity progress. In its consequence, it contributes to higher unemployment thresholds of output growth. This effect is partly offset by an increasing coefficient to GDP growth. Nevertheless, unemployment threshold of growth $\left(=\alpha_{0} / \alpha_{1}\right.$ is higher in the later period (4.5per cent GDP growth) than in the entire period (4 per cent), fixed effects disregarded. The increase in the coefficient to the GDP growth rate indicates a higher ability of the economies to transform output growth into more employment. In fixed effects estimates, a 1-percentage point reduction of the unemployment rate needs a 3 per cent GDP growth rate in the long run; the growth rate fell to 1.6 per cent between 1998 and 2004. It should be taken into account that this is growth becomes effective when the unemployment threshold has been surpassed. That means that the totally necessary GDP growth

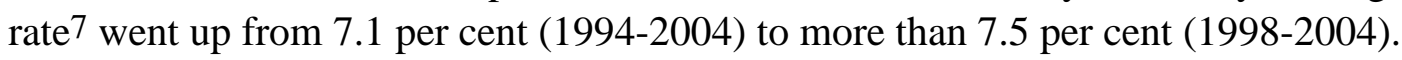

$\left.7 y=\alpha_{0} / \alpha_{1}\right)+\left(\left(1 / \alpha_{1}\right)\left(1-\alpha_{2}\right)\right.$ in reduction of the unemployment rate by $1 \mathrm{pp}$. The first term is the unemployment threshold, the second term is the long-run unemployment intensity of growth. 
Table 5:

Panel results; registered unemployment rate (first differences)

\begin{tabular}{|c|c|c|c|c|c|c|c|c|}
\hline & \multicolumn{2}{|c|}{ OLS } & \multicolumn{2}{|c|}{ TSLS (instruments) ${ }^{\mathrm{a}}$} & \multicolumn{2}{|c|}{ OLS } & \multicolumn{2}{|c|}{$\mathrm{TSLS}$ (instruments) ${ }^{\mathrm{a}}$} \\
\hline & Pooled & Fixed Effects & Pooled & Fixed Effects & Pooled & Fixed Effects & Pooled & Fixed Effects \\
\hline Period & & $94: 2-04: 4$ & & $04: 3-04: 4$ & & $98: 1-04: 4$ & & 98:1-04:4 \\
\hline $\begin{array}{l}\text { Coefficients } \\
\text { Constant }\end{array}$ & 0.001 & 0.001 & $.002 *$ & $0.003 * *$ & $0.003 * *$ & $0.004 * * *$ & $0.004 * * *$ & $0.007 * * *$ \\
\hline$y_{t}$ & $-0.035^{* *}$ & $-0.037 * *$ & $-0.054 * *$ & $-0.075^{* * *}$ & $-0.085 * * *$ & $-0.095^{* * *}$ & $-0.105^{* * *}$ & $-0.155^{* * *}$ \\
\hline$\Delta U_{t-1}$ & $0.844 * * *$ & $0.835 * * *$ & $0.910 * * *$ & $0.766^{* * * *}$ & $0.857 * * *$ & $0.836 * * *$ & $0.827 * * *$ & $0.751 * * *$ \\
\hline FE countries & no & & no & & no & & no & \\
\hline Czech Republic & & 0.001 & & 0.000 & & -0.002 & & -0.002 \\
\hline Estonia & & -0.001 & & 0.000 & & 0.001 & & 0.002 \\
\hline Hungary & & -0.000 & & -0.001 & & -0.002 & & -0.001 \\
\hline $\begin{array}{l}\text { Latvia } \\
\text { Langary }\end{array}$ & & 0.001 & & 0.001 & & 0.002 & & 0.004 \\
\hline $\begin{array}{l}\text { Latvia } \\
\text { Lithuania }\end{array}$ & & 0.000 & & 0.003 & & -0.003 & & 0.000 \\
\hline Lithuania & & 0.000 & & 0.000 & & 0.001 & & 0.001 \\
\hline $\begin{array}{l}\text { Poland } \\
\text { Slovakia }\end{array}$ & & -0.000 & & -0.000 & & -0.001 & & -0.001 \\
\hline $\begin{array}{l}\text { Slovakia } \\
\text { Slovenia }\end{array}$ & & -0.001 & & -0.001 & & -0.002 & & -0.003 \\
\hline $\begin{array}{l}\text { Summary statistics } \\
\text { Adj. } R^{2} \text {. }\end{array}$ & 0.807 & 0.804 & 0.819 & 0.808 & 0.833 & 0.835 & 0.834 & 0.824 \\
\hline Observations & $344(8 x 43)$ & $344(8 x 43)$ & $280(7 \times 40)$ & $336(8 x 42)$ & $224(8 \times 28)$ & $224(8 \times 28)$ & $216(8 \times 27)$ & $224(8 \times 28)$ \\
\hline Pooled vs. FE & & $\mathrm{F}=0.378$ & & $\mathrm{~F}=1.69$ & & $\mathrm{~F}=2.74 * * *$ & & $\mathrm{~F}=3.92 * * *$ \\
\hline
\end{tabular}

${ }^{\mathrm{a}}$ Instruments used: US t-bill rate, 2 periods lagged unemployment rates, 1 period lagged GDP growth rate, contemporaneous exports-

Standard errors have been estimated using the White robust estimation procedure. 


\section{Conclusions and policy considerations}

The unemployment rate responds to changes in output since the late 1990s, which gives evidence for completed transition. Poland and Slovakia seem to be exceptions; we explain results in isolated country regressions with sector and industry specific transition shocks. In panel regressions, these isolated effects seem to be of minor relevance. The responsiveness of unemployment to output opens options, typical for market economies, to reduce the level of unemployment inherited from earlier transition shocks. This stock of unemployment is inherited from earlier transition. One option is to increase flexibility on the labour markets (increase of the Okun coefficient), the other one is to support output growth at a path higher than until now. The study finds relatively high coefficients, and we conclude on only minor room for additional liberalization measures. This seems to confirm recent research on labour market rigidities. Furthermore, one strong obstacle in reducing this stock is technological progress, which is reflected in the increased constant. The objective to reduce unemployment more than until now would need a growth rate of output significantly higher than productivity growth, which necessitates a higher component of aggregate demand growth. Whether a lower unemployment rate, achieved by a less restrictive fiscal and monetary policy, would entail a higher inflation rate, could be answered only in estimating the NAIRU. But this is a different research issue. 


\section{References}

Aghion, Phillipe and Olivier J. Blanchard (1994): On the Speed of Transition in Central Europe, in: Stanley Fischer and Julio Rotemberg (eds), NBER Macroeconomics Annual 1994, pp. 283-320.

Bhaduri, Amit and Kazimierz Laski (1997): Lessons to be drawn from main mistakes in the transition strategy, in: Zecchini, Salvatore (ed.), Lessons from the economic transitino. Cluwer Academic Publishers, Dordrecht, Boston, London, pp. 103-123.

Blanchard, Olivier J. and Nobuhiro Kiyotaki (1987): Monopolistic competition and the effects of aggregate demand. American Economic Review, 77, pp. 647-666.

Boeri, Tito and Katherine Terrell (2002): Institutional Determinants of Labor Reallocation in Transition. Journal of Economic Perspectives, 16 (1), pp. 51-76.

Borensztein, Eduardo R. and Peter J. Montiel (1991): Savings, investment and growth in Eastern Europe. Working Paper No. 91/61. IMF, Washington D.C.

Borensztein, Eduardo R and Jonathan D. Ostry (1992): Structural and macroeconomic determinants of the output decline in Poland 1990-91. Working Paper No. 92/86, IMF, Washington D.C.

Camarero Mariam, Joseph L. Carrion-i-Silvestre and Cecilio Tamarit (2005): Employment dynamics and NAIRU estimates for accession countries. A univariate approach. Journal of Comparative Economics, 33 (3), pp. 584-603.

Castanheira, Micael and Gerard Roland (2000): The optimal speed of transition: A general equilibrium analysis. International Economic Review, 41 (1), pp. 219-39.

Cazes, Sandrine (2002): Do labour market institutions matter in transition economies. An analysis of labour market flexibility in the late nineties. International Institute for Labour Studies. Discussion Paper No. 140.

Döpke, Jörg (2001): The employment intensity of growth in Europe. Kiel Working Paper No. 1021. Kiel Institute of World Economics. Kiel.

EBRD (European Bank for Reconstruction and Development (2000): Transition Report 2000. London.

EBRD (European Bank for Reconstruction and Development (2004): Transition Report 2004. London.

EU Commission (2004): Employment in Europe 2004. Recent trends and prospects. Manuscript completed in August 2004. Brussels.

http://europa.eu.int/comm/employment_social/employment_analysis/eie/eie2004_ forew_toc_sum_en.pdf 
Federal Reserve Bank of St. Louis (2005): Economic Research.

http://research.stlouisfed.org/fred2/

Flaigg, Gebhard and Horst Rottmann (2000): Input demand and the short- and long-run employment thresholds. An empirical analysis for the German manufacturing sector. CESifo Working Paper Series No. 264. CESifo Munich.

Garibaldi, Pietro and Zuzassa Brixiova (1997): Labor market institutions and unemployment dynamics in transition economies. IMF Working Paper No. 97/137. IMF, Washington, D.C.

Halman, L (2001): The European Values Study: A Third Wave. Tilburg University, EVS, WORC, Tilburg.

Haltiwanger, John, Hartmut Lehmann and Katherine Terrell (2003): Job creation and job destruction in transition countries. Economics of Transition, 11 (2), pp. 205-219.

Hazans, Mihails (2004): Determinants of inter-regional migration in the Baltic countries. Interim paper, Cerge-EI http://www.cerge-ei.cz/pdf/gdn/RRCIII_13_paper_02.pdf, December 2004.

ILO International Labour Organization (2005): LABORSTA. http://laborsta.ilo.org

IMF International Monetary Funds (2005): International Financial Statistics.

Izyumov, Alexei and John Vahaly (2002): The unemployment-output tradeoff in transition economies: Does Okun's law apply? Economics of Planning, 35, pp. 317-331.

Kornai, Janos (1993): Transformational recession: A general phenomenon examined through the example of Hungary's development. Collegium Budapest, Institute for Advanced Studies. Discussion Paper No. 1.

Landesmann, Michael, Hermina Vidovic and Terry Ward (2005): Economic restructuring and labour market developments in the new EU member states. WIIWResearch Reports 312. Vienna.

Maddala, G. S., Kim, In-Moo (1998): Unit Roots, Cointegration, and Structural Change. Cambridge, (CUP).

Nesporova, Alenia (2002): Why unemployment remains so high in Central and Eastern Europe. Employment Paper 2002/43. ILO, Geneva.

Nickell, S. (1997): Unemployment and labour market rigidities: Europe versus North America. Journal of Economic Perspectives, 11 (3), pp. 55-74. 
Nickell, S. and R. Layard (1999): Labour market institutions and economic performance. in: Asheufelter, D. and D. Card (eds), Handbook of Labour Market Economics, Vol. 3.

OECD (1999, 2003): Employment Outlook. Paris.

Okun, Arthur M. (1962): Potential GDP: Its measurement and significance, in: Proceedings of the Business and Economics Statistics Section. American Statistical Association, pp. 98-103.

Okun, Arthur M. (1983): Potential GNP: Its Measurement and Significance, in: Joseph A. Pechman (ed.), Economics for Policymaking Selected Essays of Arthur M. Okun. MIT Press, pp. 145-159.

Prachowny, Martin F. J. (1993): Okun's law: theoretical foundations and revised estimates. The Review of Economics and Statistics, 75, pp. 331-336.

Sögner, Leopold and Alfred Stiassny (2002): An analysis on the structural stability of Okun's law - a cross-country study. Journal of Applied Economics, 34 (14), pp. 1775-1787.

Solow, R. M. (2000): Unemployment in the United States and in Europe: a Contrast and the Reasons. CESifo Working Paper, 46 (1), pp. 1-13.

UN-Economic Commission for Europe (2005): Economic Survey of Europe, No. 1. Geneva.

WIIW: Monthly Data Bank. The Vienna Institute for Comparative Economic Studies. 


\section{Appendix}

Registered unemployment is calculated by the countries' authorities according to national prescriptions, and report the share of registered unemployed in the working age population, except for Hungary and Estonia; no harmonization is available (see Table A). Although for six our of eight countries, LFS data is reported by the ILO (except for Estonia), which contains at least some standardization, the quality is not necessarily better. Survey data might suffer from many methodological defects, particularly in transition countries. LFS rates measure the share of unemployed in the labour force. Both unemployment rates differ in their levels (Tables B and C) as well partly in their first movements (first differences). 
Table A:

Registered unemployment: data sources

\begin{tabular}{|c|c|c|c|c|}
\hline Country & $\begin{array}{l}\text { Unemployment rate: ra- } \\
\text { tion of }\end{array}$ & Note 1 & Note 2 & Source \\
\hline $\begin{array}{l}\text { Czech } \\
\text { Republic }\end{array}$ & $\begin{array}{l}\text { job applicants to the sum } \\
\text { of economically active, } \\
\text { women on additional ma- } \\
\text { ternity }\end{array}$ & $\begin{array}{l}\text { From July } 2004 \\
\text { calculated with a } \\
\text { share of disposable } \\
\text { number of regis- } \\
\text { tered unemployed } \\
\text { persons }\end{array}$ & $\begin{array}{l}\text { Czech Statistical } \\
\text { Office }\end{array}$ & Via wiiw \\
\hline Estonia & $\begin{array}{l}\text { registered unemployed as } \\
\text { per cent of population } \\
\text { aged } 16 \text { to pension age }\end{array}$ & & $\begin{array}{l}\text { Estonian Statistical } \\
\text { Office }\end{array}$ & Via e-mail \\
\hline Hungary & $\begin{array}{l}\text { unemployed to total la- } \\
\text { bour force }\end{array}$ & $\begin{array}{l}\text { From may } 1995 \\
\text { methodological } \\
\text { changes }\end{array}$ & $\begin{array}{l}\text { Central Statistical } \\
\text { office }\end{array}$ & $\begin{array}{l}\text { From Jan } 2000 \\
\text { calculated by wiiw, } \\
\text { because no data of- } \\
\text { ficially published }\end{array}$ \\
\hline Latvia & $\begin{array}{l}\text { persons registered with the } \\
\text { State Employment Agency } \\
\text { as unemployed to the } \\
\text { number of economically } \\
\text { active population }\end{array}$ & & $\begin{array}{l}\text { Central Statistical } \\
\text { office }\end{array}$ & direct \\
\hline Lithuania & $\begin{array}{l}\text { registered unemployed } \\
\text { persons to the working age } \\
\text { population }\end{array}$ & & $\begin{array}{l}\text { Central Statistical } \\
\text { office }\end{array}$ & direct \\
\hline Poland & $\begin{array}{l}\text { unemployed to civilian } \\
\text { economically active }\end{array}$ & $\begin{array}{l}\text { Since Jan } 2002 \text { re- } \\
\text { vised to census } \\
2002\end{array}$ & $\begin{array}{l}\text { Central Statistical } \\
\text { office }\end{array}$ & Via wiiw \\
\hline Slovakia & $\begin{array}{l}\text { unemployed to the eco- } \\
\text { nomically active popula- } \\
\text { tion }\end{array}$ & $\begin{array}{l}\text { From Dec 1997: } \\
\text { share of disposable } \\
\text { number of regis- } \\
\text { tered unemployed } \\
\text { to the economically } \\
\text { active persons of } \\
\text { the previous year }\end{array}$ & $\begin{array}{l}\text { From } 1 \text { August } \\
2000 \text { new law on } \\
\text { unemployment } \\
\text { benefits }\end{array}$ & $\begin{array}{l}\text { Slovak Statistical } \\
\text { office, Via wiiw }\end{array}$ \\
\hline Slovenia & $\begin{array}{l}\text { unemployed to the } \\
\text { economicaly active popu- } \\
\text { lation }\end{array}$ & & Bank of Slovenia & Via wiiw \\
\hline
\end{tabular}


Table B:

Quarterly $^{\mathrm{a}}$ registered unemployment rates, per cent ${ }^{\mathrm{b}}$

\begin{tabular}{|c|c|c|c|c|c|c|c|c|c|}
\hline \multicolumn{2}{|c|}{ Quarter } & Czech Republic & Estonia & Hungary & Latria & Lithuania & Poland & Slovakia & Slovenia \\
\hline \multirow[t]{4}{*}{1994} & 1 & 3.67 & 6.9 & 13.13 & 6.27 & 3.63 & 16.73 & 15.00 & 15.00 \\
\hline & 2 & 3.17 & 7.0 & 11.97 & 6.47 & 3.40 & 16.40 & 14.30 & 14.23 \\
\hline & 3 & 3.20 & 5.8 & 11.57 & 6.30 & 3.27 & 16.73 & 14.63 & 14.30 \\
\hline & 4 & 3.12 & 5.8 & 11.00 & 6.37 & 4.17 & 16.10 & 14.57 & 14.27 \\
\hline \multirow[t]{4}{*}{1995} & 1 & 3.28 & 6.5 & 11.93 & 6.70 & 5.43 & 15.83 & 14.97 & 13.93 \\
\hline & 2 & 2.81 & 6.2 & 11.00 & 6.30 & 5.87 & 15.07 & 13.50 & 13.50 \\
\hline & 3 & 2.95 & 5.6 & 10.90 & 6.07 & 6.13 & 15.17 & 13.33 & 13.93 \\
\hline & 4 & 2.86 & 5.9 & 10.67 & 6.30 & 7.03 & 14.77 & 12.90 & 14.43 \\
\hline \multirow[t]{4}{*}{1996} & 1 & 3.10 & 7.0 & 11.77 & 6.80 & 8.13 & 15.43 & 13.57 & 14.17 \\
\hline & 2 & 2.76 & 6.6 & 11.10 & 7.07 & 7.47 & 14.70 & 12.17 & 13.60 \\
\hline & 3 & 3.10 & 6.2 & 11.13 & 7.07 & 6.60 & 13.80 & 12.33 & 13.50 \\
\hline & 4 & 3.36 & 6.4 & 10.87 & 7.13 & 6.33 & 13.23 & 12.33 & 14.13 \\
\hline \multirow[t]{4}{*}{1997} & 1 & 4.00 & 6.7 & 11.00 & 7.50 & 6.27 & 12.90 & 13.57 & 14.50 \\
\hline & 2 & 3.86 & 6.1 & 10.57 & 7.83 & 5.60 & 11.80 & 12.53 & 14.17 \\
\hline & 3 & 4.55 & 5.3 & 10.40 & 7.50 & 5.43 & 10.97 & 12.87 & 14.40 \\
\hline & 4 & 5.01 & 5.3 & 10.27 & 7.03 & 6.30 & 10.30 & 12.67 & 14.60 \\
\hline \multirow[t]{4}{*}{1998} & 1 & 5.56 & 5.9 & 11.17 & 7.03 & 7.47 & 10.57 & 13.47 & 14.87 \\
\hline & 2 & 5.44 & 5.5 & 10.03 & 7.10 & 6.20 & 9.77 & 13.20 & 14.27 \\
\hline & 3 & 6.42 & 5.1 & 9.57 & 7.43 & 5.47 & 9.57 & 13.90 & 14.23 \\
\hline & 4 & 7.10 & 5.7 & 9.40 & 8.73 & 6.47 & 10.00 & 14.67 & 14.57 \\
\hline \multirow[t]{4}{*}{1999} & 1 & 8.23 & 7.3 & 10.40 & 9.77 & 8.10 & 11.77 & 16.50 & 14.30 \\
\hline & 2 & 8.23 & 7.8 & 9.67 & 10.10 & 7.80 & 11.67 & 16.87 & 13.70 \\
\hline & 3 & 8.93 & 7.6 & 9.43 & 9.73 & 8.10 & 11.93 & 18.10 & 13.27 \\
\hline & 4 & 9.08 & 7.8 & 9.33 & 9.17 & 9.47 & 12.60 & 18.40 & 13.00 \\
\hline \multirow[t]{4}{*}{2000} & 1 & 9.65 & 8.4 & 10.10 & 9.07 & 11.13 & 13.90 & 19.43 & 12.97 \\
\hline & 2 & 8.80 & 7.8 & 9.17 & 8.67 & 11.13 & 13.67 & 18.83 & 12.07 \\
\hline & 3 & 8.92 & 7.2 & 8.67 & 8.07 & 11.73 & 13.90 & 17.80 & 11.77 \\
\hline & 4 & 8.60 & 8.6 & 8.53 & 7.80 & 12.13 & 14.57 & 16.90 & 11.93 \\
\hline \multirow[t]{4}{*}{2001} & 1 & 8.92 & 8.9 & 9.30 & 8.00 & 13.17 & 15.90 & 19.57 & 12.00 \\
\hline & 2 & 8.17 & 8.4 & 8.57 & 7.90 & 12.40 & 15.93 & 17.87 & 11.40 \\
\hline & 3 & 8.49 & 8.0 & 8.13 & 7.67 & 12.07 & 16.17 & 17.73 & 11.23 \\
\hline & 4 & 8.59 & 8.6 & 7.73 & 7.63 & 12.53 & 16.90 & 17.87 & 11.63 \\
\hline \multirow[t]{4}{*}{2002} & 1 & 9.27 & 9.0 & 8.70 & 9.13 & 12.87 & 20.13 & 19.47 & 11.83 \\
\hline & 2 & 8.70 & 7.7 & 7.83 & 9.00 & 11.20 & 19.50 & 17.80 & 11.43 \\
\hline & 3 & 9.33 & 7.1 & 7.80 & 8.87 & 10.63 & 19.47 & 17.13 & 11.60 \\
\hline & 4 & 9.48 & 7.1 & 7.77 & 8.57 & 10.67 & 19.73 & 16.90 & 11.50 \\
\hline \multirow[t]{4}{*}{2003} & 1 & 10.15 & 7.9 & 8.90 & 8.83 & 12.00 & 20.63 & 17.10 & 11.47 \\
\hline & 2 & 9.53 & 7.2 & 8.20 & 8.70 & 10.07 & 19.93 & 14.93 & 10.93 \\
\hline & 3 & 9.97 & 6.4 & 8.03 & 8.50 & 9.50 & 19.50 & 14.23 & 11.20 \\
\hline & 4 & 10.04 & 6.5 & 8.10 & 8.53 & 9.57 & 19.60 & 14.53 & 11.10 \\
\hline \multirow[t]{4}{*}{2004} & 1 & 10.78 & 7.0 & 9.10 & 9.00 & 8.00 & 20.57 & 16.37 & 11.20 \\
\hline & 2 & 10.00 & 6.1 & 8.40 & 8.80 & 7.03 & 19.70 & 14.57 & 10.47 \\
\hline & 3 & 9.20 & 5.3 & 8.30 & 8.70 & 6.40 & 19.10 & 13.30 & 10.30 \\
\hline & 4 & 9.10 & 5.3 & 8.80 & 8.50 & 5.90 & 18.80 & 12.80 & 10.30 \\
\hline
\end{tabular}

${ }^{a}$ For all countries, except Estonia, extrapolated from monthly unemployment rates. 1994 data for Estonia: extrapolated from trend data for 1993. $-{ }^{b}$ of the economically active population, except Estonia and Hungary: per cent of the labour force.

Sources: List of Table A; own calculations. 
Table C:

Quarterly LFS ${ }^{\mathrm{a}}$ unemployment rates (in \% of the labour force)

\begin{tabular}{|c|c|c|c|c|c|c|c|}
\hline \multicolumn{2}{|c|}{ Quarter } & Czech Republic & Estonia & Hungary & Poland & Slovakia & Slovenia \\
\hline \multirow[t]{4}{*}{1994} & 1 & 3.70 & 7.6 & 11.50 & 15.90 & 13.70 & n. a. \\
\hline & 2 & 3.90 & 7.4 & 10.70 & 14.00 & 13.40 & n. a. \\
\hline & 3 & 3.80 & 7.6 & 10.30 & 13.90 & 13.40 & n. a. \\
\hline & 4 & 4.00 & 7.7 & 10.30 & 13.90 & 14.10 & n. a. \\
\hline \multirow[t]{4}{*}{1995} & 1 & 3.50 & 9.8 & 10.60 & 14.70 & 14.30 & n. a. \\
\hline & 2 & 3.60 & 9.7 & 10.10 & 12.60 & 13.30 & n. a. \\
\hline & 3 & 3.30 & 9.7 & 10.10 & 12.90 & 12.40 & n. a. \\
\hline & 4 & 3.40 & 9.7 & 9.90 & 13.10 & 12.40 & n. a. \\
\hline \multirow[t]{4}{*}{1996} & 1 & 3.60 & 9.8 & 10.50 & 14.00 & 12.30 & n. a. \\
\hline & 2 & 4.10 & 9.6 & 9.90 & 12.40 & 11.20 & n. a. \\
\hline & 3 & 3.90 & 10 & 9.90 & 11.60 & 10.90 & n. a. \\
\hline & 4 & 4.30 & 10.4 & 9.20 & 11.50 & 10.90 & n. a. \\
\hline \multirow[t]{4}{*}{1997} & 1 & 4.30 & 9.6 & 9.40 & 12.80 & 12.00 & n. a. \\
\hline & 2 & 4.50 & 9.5 & 9.20 & 11.30 & 11.40 & 7.10 \\
\hline & 3 & 5.00 & 9.9 & 8.60 & 10.70 & 12.00 & 7.20 \\
\hline & 4 & 5.40 & 9.8 & 7.70 & 10.20 & 11.80 & 7.80 \\
\hline \multirow[t]{4}{*}{1998} & 1 & 5.90 & 10.1 & 8.70 & 11.10 & 12.60 & 8.40 \\
\hline & 2 & 5.90 & 9.6 & 8.00 & 10.20 & 12.10 & 7.70 \\
\hline & 3 & 6.80 & 9.6 & 7.50 & 10.30 & 12.70 & 7.50 \\
\hline & 4 & 7.26 & 10.2 & 7.00 & 10.60 & 12.50 & 7.80 \\
\hline \multirow[t]{4}{*}{1999} & 1 & 8.40 & 12 & 7.40 & 12.50 & 15.30 & 7.70 \\
\hline & 2 & 8.40 & 11.6 & 6.90 & 0.00 & 15.80 & 7.40 \\
\hline & 3 & 9.00 & 12.4 & 7.00 & 0.00 & 16.70 & 7.50 \\
\hline & 4 & 9.00 & 13 & 6.50 & 15.30 & 17.10 & 7.70 \\
\hline \multirow[t]{4}{*}{2000} & 1 & 9.50 & 14.8 & 6.70 & 16.70 & 18.90 & 7.50 \\
\hline & 2 & 8.70 & 13.1 & 6.50 & 16.30 & 18.90 & 7.20 \\
\hline & 3 & 8.50 & 12.8 & 6.30 & 15.40 & 18.50 & 6.70 \\
\hline & 4 & 8.30 & 14 & 6.00 & 16.00 & 18.00 & 6.60 \\
\hline \multirow[t]{4}{*}{2001} & 1 & 8.50 & 14.2 & 6.00 & 18.20 & 19.70 & 6.70 \\
\hline & 2 & 8.00 & 12.4 & 5.60 & 18.40 & 19.20 & 5.90 \\
\hline & 3 & 8.20 & 12 & 5.60 & 17.90 & 19.00 & 5.90 \\
\hline & 4 & 7.80 & 12 & 5.60 & 18.50 & 18.70 & 7.10 \\
\hline \multirow[t]{4}{*}{2002} & 1 & 7.70 & 11.3 & 5.80 & 20.30 & 19.40 & 6.90 \\
\hline & 2 & 7.00 & 9.5 & 5.60 & 19.90 & 18.60 & 5.90 \\
\hline & 3 & 7.20 & 9.2 & 5.90 & 19.80 & 18.20 & 6.00 \\
\hline & 4 & 7.30 & 11.4 & 5.90 & 19.70 & 17.90 & 6.50 \\
\hline \multirow[t]{4}{*}{2003} & 1 & 7.60 & 10.7 & 6.40 & 20.60 & 18.40 & 7.00 \\
\hline & 2 & 7.50 & 10.8 & 5.80 & 19.40 & 17.00 & 6.60 \\
\hline & 3 & 8.00 & 9.6 & 5.70 & 19.40 & 17.00 & 6.60 \\
\hline & 4 & 8.10 & 9.4 & 5.50 & 19.30 & 17.40 & 6.70 \\
\hline \multirow[t]{4}{*}{2004} & 1 & 8.70 & 10.2 & 6.10 & 20.70 & 19.30 & 6.80 \\
\hline & 2 & 8.20 & 10.1 & 5.80 & 19.10 & 18.50 & 6.10 \\
\hline & 3 & 8.20 & 10 & 6.10 & 18.20 & 17.50 & 6.00 \\
\hline & 4 & 8.20 & 8.6 & 6.30 & 18.00 & 17.10 & 6.40 \\
\hline
\end{tabular}

${ }^{a}$ Labour Force Survey.

Sources: For all countries, except Estonia: ILO; Estonia: National statistical office. 
Table D:

Annualized $^{\text {a }}$ quarterly GDP growth rates, 1994:1 - 2004:4

\begin{tabular}{|c|c|c|c|c|c|c|c|c|c|}
\hline \multicolumn{2}{|c|}{ Quarter } & Czech Republic & Estonia & Hungary & Latvia & Lithuania & Poland & Slovakia & Slovenia \\
\hline \multirow[t]{4}{*}{1994} & 1 & 0.071 & 0.044 & 0.036 & 0.074 & 0.046 & 0.035 & 0.053 & 0.046 \\
\hline & 2 & 0.066 & -0.026 & 0.029 & 0.035 & 0.196 & 0.027 & 0.052 & 0.073 \\
\hline & 3 & 0.050 & -0.057 & 0.024 & 0.000 & 0.060 & 0.015 & 0.073 & 0.041 \\
\hline & 4 & 0.048 & -0.048 & 0.019 & 0.064 & 0.014 & 0.016 & 0.070 & 0.053 \\
\hline \multirow[t]{4}{*}{1995} & 1 & 0.062 & 0.021 & -0.003 & 0.035 & -0.010 & 0.019 & 0.045 & 0.062 \\
\hline & 2 & 0.064 & 0.060 & -0.036 & -0.005 & 0.025 & 0.034 & 0.071 & 0.034 \\
\hline & 3 & 0.063 & 0.082 & -0.019 & -0.030 & 0.048 & 0.086 & 0.058 & 0.050 \\
\hline & 4 & 0.049 & 0.071 & -0.003 & -0.034 & 0.057 & 0.124 & 0.058 & 0.020 \\
\hline \multirow[t]{4}{*}{1996} & 1 & 0.045 & 0.036 & 0.006 & 0.031 & 0.027 & 0.081 & 0.061 & 0.023 \\
\hline & 2 & 0.048 & 0.036 & 0.007 & 0.020 & 0.010 & 0.084 & 0.061 & 0.028 \\
\hline & 3 & 0.047 & 0.034 & 0.009 & 0.054 & 0.078 & 0.056 & 0.061 & 0.041 \\
\hline & 4 & 0.033 & 0.053 & 0.030 & 0.046 & 0.067 & 0.025 & 0.061 & 0.049 \\
\hline \multirow[t]{4}{*}{1997} & 1 & 0.016 & 0.044 & 0.023 & 0.059 & 0.041 & 0.063 & 0.049 & 0.040 \\
\hline & 2 & -0.003 & 0.108 & 0.048 & 0.084 & 0.084 & 0.054 & 0.049 & 0.064 \\
\hline & 3 & -0.023 & 0.112 & 0.057 & 0.094 & 0.061 & 0.039 & 0.055 & 0.045 \\
\hline & 4 & -0.020 & 0.124 & 0.053 & 0.093 & 0.102 & 0.113 & 0.032 & 0.034 \\
\hline \multirow[t]{4}{*}{1998} & 1 & -0.016 & 0.104 & 0.044 & 0.085 & 0.085 & 0.059 & 0.062 & 0.060 \\
\hline & 2 & -0.011 & 0.068 & 0.049 & 0.063 & 0.100 & 0.045 & 0.054 & 0.025 \\
\hline & 3 & -0.007 & 0.025 & 0.054 & 0.039 & 0.041 & 0.054 & 0.047 & 0.033 \\
\hline & 4 & -0.008 & -0.004 & 0.047 & 0.005 & -0.009 & 0.036 & 0.007 & 0.035 \\
\hline \multirow[t]{4}{*}{1999} & 1 & -0.009 & -0.009 & 0.032 & 0.025 & -0.016 & 0.014 & 0.006 & 0.029 \\
\hline & 2 & -0.003 & -0.011 & 0.033 & 0.024 & -0.020 & 0.035 & 0.024 & 0.078 \\
\hline & 3 & 0.011 & -0.005 & 0.042 & 0.031 & -0.066 & 0.042 & -0.001 & 0.045 \\
\hline & 4 & 0.019 & 0.020 & 0.059 & 0.052 & -0.048 & 0.069 & 0.031 & 0.055 \\
\hline \multirow[t]{4}{*}{2000} & 1 & 0.030 & 0.069 & 0.066 & 0.061 & 0.043 & 0.065 & 0.016 & 0.066 \\
\hline & 2 & 0.032 & 0.093 & 0.057 & 0.057 & 0.014 & 0.049 & 0.020 & 0.032 \\
\hline & 3 & 0.031 & 0.082 & 0.046 & 0.070 & 0.038 & 0.022 & 0.024 & 0.057 \\
\hline & 4 & 0.037 & 0.068 & 0.042 & 0.088 & 0.062 & 0.026 & 0.021 & 0.031 \\
\hline \multirow[t]{4}{*}{2001} & 1 & 0.035 & 0.065 & 0.042 & 0.085 & 0.055 & 0.021 & 0.034 & 0.031 \\
\hline & 2 & 0.033 & 0.060 & 0.041 & 0.094 & 0.053 & 0.006 & 0.030 & 0.028 \\
\hline & 3 & 0.030 & 0.060 & 0.039 & 0.069 & 0.068 & 0.013 & 0.038 & 0.030 \\
\hline & 4 & 0.026 & 0.070 & 0.033 & 0.072 & 0.079 & 0.003 & 0.051 & 0.025 \\
\hline \multirow[t]{4}{*}{2002} & 1 & 0.023 & 0.037 & 0.031 & 0.041 & 0.042 & 0.007 & 0.039 & 0.024 \\
\hline & 2 & 0.021 & 0.094 & 0.032 & 0.053 & 0.078 & 0.016 & 0.040 & 0.030 \\
\hline & 3 & 0.017 & 0.094 & 0.037 & 0.077 & 0.079 & 0.017 & 0.043 & 0.032 \\
\hline & 4 & 0.017 & 0.063 & 0.039 & 0.086 & 0.068 & 0.015 & 0.054 & 0.031 \\
\hline \multirow[t]{4}{*}{2003} & 1 & 0.023 & 0.058 & 0.027 & 0.088 & 0.096 & 0.027 & 0.041 & 0.022 \\
\hline & 2 & 0.028 & 0.035 & 0.025 & 0.062 & 0.068 & 0.046 & 0.038 & 0.021 \\
\hline & 3 & 0.033 & 0.052 & 0.029 & 0.073 & 0.088 & 0.038 & 0.042 & 0.023 \\
\hline & 4 & 0.032 & 0.062 & 0.036 & 0.075 & 0.106 & 0.042 & 0.047 & 0.025 \\
\hline \multirow[t]{4}{*}{2004} & 1 & 0.033 & 0.068 & 0.043 & 0.087 & 0.071 & 0.076 & 0.054 & 0.041 \\
\hline & 2 & 0.039 & 0.059 & 0.042 & 0.077 & 0.073 & 0.063 & 0.055 & 0.049 \\
\hline & 3 & 0.036 & 0.061 & 0.037 & 0.091 & 0.058 & 0.043 & 0.053 & 0.045 \\
\hline & 4 & 0.043 & 0.059 & 0.038 & 0.086 & 0.067 & 0.035 & 0.058 & 0.043 \\
\hline
\end{tabular}

${ }^{\text {a }}$ Quarter as against the previous year's quarter.

Sources: OECD, national statistical offices; own calculations. 
Instruments: Exports of accession countries (mn US dollars): WIIW monthly data bank for Czech Republic, Hungary, Poland and Slovakia (quarterly averages calculated from monthly data). IMF-International Financial Statistics (2005): commodity exports according balance of payments statistics for Slovenia and Lithuania. National statistical offices for Estonia and Latvia. US registered unemployment rate and 10 years treasury bill rates are taken from the Federal Reserve Bank of St. Louis 2005.

Table E:

OLS regressions; registered unemployment rate (first differences) Period: 94:2 - 04:4; observations: 43

\begin{tabular}{|c|c|c|c|c|c|c|c|c|}
\hline \multirow{2}{*}{ Country } & \multicolumn{3}{|c|}{ Coefficients } & \multirow{2}{*}{ Adj. $R^{2}$} & \multirow{2}{*}{ Q-stat (10) } & \multicolumn{2}{|c|}{ Stability } & \multirow{2}{*}{ JB } \\
\hline & Constant & $y_{1}$ & $\Delta U_{t-1}$ & & & $\mathrm{CS}$ & $\mathrm{CS}^{2}$ & \\
\hline $\begin{array}{l}\text { Czech } \\
\text { Republic }\end{array}$ & $0.004 * * *$ & $-0.110 * * *$ & $0.780 * * *$ & 0.899 & $24.59 * * *$ & $\mathrm{~s}$ & n.s. & $29.91 * * *$ \\
\hline Estonia & 0.002 & $-0.055^{* *}$ & $0.505^{* * *} *$ & 0.64 & $36.82 * * *$ & s. & s. & 0.24 \\
\hline Hungary & 0.001 & -0.036 & $0.905 * * *$ & 0.684 & 8.24 & $\mathrm{~s}$ & n.s & $9.59 * * *$ \\
\hline Latvia & 0.003 & $-0.048 *$ & $0.720 * * *$ & 0.671 & $42.20 * * *$ & $\mathrm{~s}$ & $\mathrm{~s}$ & 0.968 \\
\hline Lithuania & 0.001 & -0.032 & $0.919 * * *$ & 0.835 & 5.20 & $\mathrm{~s}$ & $\mathrm{~s}$ & $10.24 * * *$ \\
\hline Poland & 0.001 & -0.028 & $0.901 * * *$ & 0.861 & $16.08 *$ & n.s. & s. & $6.70 * *$ \\
\hline Slovakia & 0.005 & -0.121 & $0.802 * * *$ & 0.786 & $17.94^{*}$ & s. & n.s. & 1.04 \\
\hline Slovenia & 0.001 & $-0.063 *$ & $0.724 * * *$ & 0.658 & $19.11^{* *}$ & n.s. & n.s. & 0.266 \\
\hline
\end{tabular}

$* 10 \%, * * 5 \%$, *** 1\%; s: stable, n.s.: not stable. CS: CUSUM, CS ${ }^{2}$ CUSUM squared. 